\title{
Physiological and agronomic characteristics of the common bean as affected by multifunctional microorganisms
}

\section{Características fisiológicas e agronômicas do feijão comum influenciados por microrganismos multifuncionais}

\begin{abstract}
Cássia Cristina Rezende ${ }^{\text {*; }}$ Laylla Luanna de Mello Frasca2; Mariana Aguiar Silva2; Rafael Augusto Corrêa Pires ${ }^{3}$; Anna Cristina Lanna4; Marta Cristina Corsi de Filippi ${ }^{4}$; Adriano Stephan Nascente ${ }^{4}$
\end{abstract}

Highlights

Multifunctional microorganisms (MMs) can have beneficial effects on plants.

We tested the use of MMs on common bean plant development.

MMs resulted in improved agronomic performance on common bean plants.

MMs resulted in higher accumulation of biomass and N, P and $\mathrm{K}$ in the shoots.

\begin{abstract}
Multifunctional microorganisms (MMs) can have beneficial effects on plants through direct and indirect mechanisms. This study aimed to determine the effect of MMs on shoot and root biomass production; gas exchange; content of macronutrients in the shoots, roots and grains; yield components; and grain yield of common bean plants. A completely randomized design with twenty-six treatments and three replications was used under controlled conditions. Treatments consisted of the application of MMs and their combinations in pairs, with the nine rhizobacteria isolates BRM 32109, BRM 32110 and 1301 (Bacillus sp.), BRM 32111 and BRM 32112 (Pseudomonas sp.), BRM 32113 (Burkholderia sp.), BRM 32114 (Serratia sp.), 1381 (Azospirillum sp.) and Ab-V5 (Azospirillum brasilense); an edaphic fungal isolate T-26 (Trichoderma koningiopsis); and a control (without MMs). These MMs were applied at three time points: microbiolization of the seeds, watering the soil seven days after sowing (DAS) and spraying the plants with 21 DAS. In comparison to the control

1 Student of the Master's Course of the Graduate Program in Agronomy, Federal University of Goiás, UFG, Goiânia, GO, Brazil. E-mail: cassiacristinarezende@hotmail.com

2 Students of the Doctoral Course of the Graduate Program in Agronomy, UFG, Goiânia, GO, Brazil. E-mail: laylla. frasca@gmail.com; marianaaguiar23@hotmail.com

${ }^{3}$ Student of the Graduation Course in Agronomy, University Center of Goiás, Uni-ANHANGUERA, Goiânia, GO, Brazil. E-mail: rafaelaugusto.correa@gmail.com

${ }^{4}$ Researchers, Brazilian Agricultural Research Corporation, EMBRAPA, Santo Antônio de Goiás, GO, Brazil. E-mail: anna.lanna@embrapa.br; cristina.filippi@embrapa.br; adriano.nascente@embrapa.br

* Author for correspondence
\end{abstract}

Received: July 20, 2020 - Approved: Sept. 18, 2020 
plants, the isolates 1301 and T-26, in addition to the combinations Ab-V5 + T-26, BRM $32114+$ BRM 32110 and $1381+\mathrm{T}-26$, provided better results, with an increase of $36.5 \%$ in the grain yield, a higher accumulation of biomass (78.0\%) and a higher content of $\mathrm{N}, \mathrm{P}$ and $\mathrm{K}(42.6,67.8$ and $25.7 \%$, respectively) in the shoots of common bean plants. Therefore, the results allow us to infer that the use of MMs is a good strategy for increasing common bean grain yields.

Key words: Coinoculation. Fungus. Grain yield. Phaseolus vulgaris. Rhizobacteria.

\section{Resumo}

Microrganismos multifuncionais (MM) podem proporcionar efeitos benéficos nas plantas através de mecanismos diretos e indiretos. Este estudo teve como objetivo determinar o efeito do MM na produção de biomassa da parte aérea e da raiz, nas trocas gasosas, no teor de macronutrientes na parte aérea, na raiz e nos grãos, nos componentes de produção e na produção de grãos de feijão-comum. O delineamento experimental foi o inteiramente casualizado, com 26 tratamentos e três repetições, em condições controladas. Os tratamentos consistiram na aplicação de MM e suas combinações em pares, com nove rizobactérias isolados BRM 32109, BRM 32110 e 1301 (Bacillus sp.), BRM 32111 e BRM 32112 (Pseudomonas sp.), BRM 32113 (Burkholderia sp.), BRM 32114 (Serratia sp.), 1381 (Azospirillum sp.) e Ab-V5 (Azospirillum brasilense), um isolado fúngico edáfico T-26 (Trichoderma koningiopsis) e um controle (sem MM). Esses MM foram aplicados em três momentos: microbiolização das sementes, rega do solo sete dias após a semeadura (DAS) e pulverização das plantas 21 DAS. Os isolados 1301 e T-26, além das combinações AbV5 + T-26, BRM 32114 + BRM 32110 e 1381 + T-26 proporcionaram melhores resultados, uma vez que permitiram aumentar $36,5 \%$ na produção de grãos, maior acúmulo de biomassa $(78,0 \%)$ e maior teor de $\mathrm{N}$, P e K (42,6; 67,8 e 25,7\%, respectivamente) na parte aérea do feijão-comum, comparativamente as plantas controle. Portanto, os resultados permitem inferir que o uso de MMs é uma boa estratégia para proporcionar aumentos no rendimento de grãos de feijão-comum.

Palavras-chave: Coinoculação. Fungo. Phaseolus vulgaris. Produtividade. Rizobactérias.

\section{Introduction}

The common bean (Phaseolus vulgaris L.) is an agricultural product with high sociocultural and nutritional importance to Brazil since it is the main source of vegetable protein for direct consumption by low-income populations (Ganascini et al., 2019). The cultivation of common bean, both alone and intercropped with other crops, is carried out in all Brazilian states (Faria et al., 2016).

Given the economic and social importance of common beans in Brazil, in addition to the growing world demand for food and limitations in the expansion of agricultural areas, investment in research and development by sustainable technologies is necessary (F. C. Oliveira, Benett, Benett, Silva, \& Vieira, 2017). Multifunctional microorganisms (MMs) have been incorporated as a very efficient strategy in food production since they have the potential to promote plant growth and control pests and diseases through direct mechanisms that occur during the production of compounds or facilitate the absorption of certain nutrients, such as the biological fixation of atmospheric nitrogen, the solubilization of inorganic phosphate, and the production of plant growth 
hormones and through indirect mechanisms that can contribute to reducing or preventing the deleterious effects of phytopathogenic microorganisms. Thus, it is possible to reduce the use of agrochemicals and production costs, in addition to providing significant increases in the grain yields of crops (Glick, 2012).

As an example of MMs, rhizobacteria habitats are the rhizosphere of plants, where they multiply, survive and protect themselves from the antagonistic action of the remaining soil microbiota (Podile \& Kishore, 2006). The rhizobacteria that establish a beneficial association with plants have been specifically called plant growth promoting rhizobacteria (PGPR)(Glick, 2012). Dey, Pal, Bhattand Chauhan (2004) evaluated isolates of Pseudomonas spp. in peanut (Arachis hypogaea L.) crop and concluded that some isolates significantly increased pod yield, nodule yield and dry weight, root length and number of pods. In another study, seed treatment with the rhizobacterium Bacillus subtilis increased the production of dry matter from seedlings and roots of common bean (G. R. F. Oliveira, Silva, Marciano, Proença, \& Sá, 2016).

Others examples of MMs are some species of soil fungi, which also have the potential to promote growth in plants such as Trichoderma spp. (Druzhinina et al., 2011; Machado, Parzianello, Silva, \& Antoniolli, 2012). Souza, Harakava, Lucon and Guzzo (2012) reported that the most efficient isolates of Trichoderma spp. (T. harzianum, T. strigosum and $T$. theobromicola) provided increases in the dry matter production of common bean shoots and reduced the severity of anthracnose
(Colletotrichum lindemuthianum). Chagas, Chagas, Soares and Fidelis (2017) showed that inoculation of soybeans (Glycine max), cowpea (Vigna unguiculata), rice (Oryza sativa) and corn (Zea mays) with Trichoderma asperellum isolate UFT 201 provided increased the biomass production of the shoots in relation to that with the control for all crops.

Studies conducted by Filippi et al. (2011) and França et al. (2015) identified several multifunctional microorganisms in the upland rice rhizosphere. These MMs were evaluated in controlled and field conditions and showed many beneficial effects related to gas exchange, production of shoot biomass, nutrient content and grain yield of upland rice (Nascente et al., 2017a, 2019a,b) and irrigated rice (Nascente et al., 2017b). Such multifunctional microorganisms, isolated and/ or in combination, can be promising for use in other agricultural crops.

Coinoculation consists of adding two or more MMs together in a crop to maximize the beneficial effects of their interactions in a target plant (Chibeba et al., 2015). Studies using coinoculation of microorganisms are important to identifying combinations that provide better plant development (Benizri, Baudoin, \& Guckert, 2001). However, studies using multifunctional microorganisms in common bean plants are rare. Therefore, the objective of this study was to evaluate the effect of isolated or combined multifunctional microorganisms on shoot and root biomass production; gas exchange; macronutrient content in shoots, roots and grains; yield components; and grain yield of common bean plants. 


\section{Material and Methods}

\section{Characterization of the environment}

The experiment was carried out in a greenhouse at the Embrapa Arroz e Feijão, Santo Antônio de Goiás, Goias, Brazil. Soil from the arable layer (0.00-0.20 m) of a clay-textured Typic Acrustox (United States Department of Agriculture [USDA], 1996) was used. The chemical characteristics of the soil were determined according to methods proposed by Donagema, Campos, Calderano, Teixeira and Viana (2011), and the results were as follows: $\mathrm{pH}\left(\mathrm{H}_{2} \mathrm{O}\right)=6.1 ; \mathrm{Ca}^{2+}=78.4$ mmolc $\mathrm{dm}$ 3; $\mathrm{Mg}^{2+}=20.9$ mmolc dm- ${ }^{3} ; \mathrm{H}+\mathrm{Al}^{3+}=12$ mmolc dm-3; $\mathrm{P}=35.9 \mathrm{mg} \mathrm{dm}-3 ; \mathrm{K}+=203 \mathrm{mg} \mathrm{dm}-3$; $\mathrm{Cu}^{2+}=2.4 \mathrm{mg} \mathrm{dm}-{ }^{3} ; \mathrm{Zn}^{2+}=2.9 \mathrm{mg} \mathrm{dm}-{ }^{3} ; \mathrm{Fe}^{3+}$ $=39 \mathrm{mg} \mathrm{dm}-3 ; \mathrm{Mn}^{2+}=28 \mathrm{mg} \mathrm{dm}^{-3} ;$ and organic matter $=24.7 \mathrm{~g} \mathrm{~kg}^{-1}$.

Three weeks before the sowing of common bean, 78 pots with a capacity of $7 \mathrm{~kg}$ were completely filled with soil and fertilized with $10 \mathrm{~g}$ of NPK, 5-30-15. During the experiment, water in the soil was monitored daily and maintained under field capacity conditions.

\section{Experimental design and treatments}

A completely randomized design with 26 treatments and three replications was used. The treatments consisted of the microbiolization of common bean seeds, cultivar BRS UAI (most recent cultivar released by Embrapa Rice and Beans), with suspension of microorganisms previously selected as MMs and their combinations in pairs, with nine rhizobacteria isolates and one soil fungus isolate (Table 1). Additionally, at 7 and 21 days, solutions with the microorganisms were applied according to each treatment. In the control treatment, water was used instead of suspensions of microorganisms.

The main characteristics of the rhizobacteria isolates BRM 32109 (Bacillus sp.), BRM 32110 (Bacillus thuringiensis), BRM 32111 (Pseudomonas fluorescens), BRM 32112 (Pseudomonas sp.), BRM 32113 (Burkholderia pyrrocinia), BRM 32114 (Serratia sp.), 1301 (Bacillus sp.), 1381 (Azospirillum sp.), Ab-V5 (Azospirillum brasilense) and the T-26 fungus (Trichoderma koningiopsis) were described (Table 2). The microorganisms used are deposited and preserved in the collection of Multifunctional Microorganisms of Embrapa Arroz e Feijão. 
Table 1

Multifunctional microorganisms, isolated or combined, used during the cultivation of common bean, cultivar BRS Uai

\begin{tabular}{|clrl|}
\hline Treatments & \multicolumn{1}{c}{ Microorganisms } & Treatments & \multicolumn{1}{c|}{ Microorganisms } \\
\hline 1 & BRM 32109 (Bacillus sp.) & 14 & $1301+$ BRM 32114 \\
\hline 2 & BRM 32110 (Bacillus thunringiensis) & 15 & $1381+$ BRM 32114 \\
\hline 3 & BRM 32111 (Pseudomonas fluorescens) & 16 & $1381+1301$ \\
\hline 4 & BRM 32112 (Pseudomonas sp.) & 17 & BRM 32110 + Ab-V5 \\
\hline 5 & BRM 32113 (Burkholderia pyrrocinia) & 18 & BRM 32114 + Ab-V5 \\
\hline 6 & BRM 32114 (Serratia sp.) & 19 & $1301+$ Ab-V5 \\
\hline 7 & T-26 (Trichoderma koningiopsis) & 20 & $1381+$ Ab-V5 \\
\hline 8 & Ab-V5 (Azospirillum brasilense) & 21 & Ab-V5 + T-26 \\
\hline 9 & 1381 (Azospirillum sp.) & 22 & BRM 32110 + T-26 \\
\hline 10 & 1301 (Bacillus sp.) & 23 & BRM 32114 + T-26 \\
\hline 11 & BRM 32114 + BRM 32110 & 24 & $1301+$ T-26 \\
\hline 12 & $1301+$ BRM 32110 & 25 & $1381+$ T-26 \\
\hline 13 & $1381+$ BRM 32110 & 26 & Control \\
\hline
\end{tabular}

Table 2

Collection code, geographical origin, biochemical characteristics and taxonomic classification of the nine rhizobacteria isolates and one fungus isolate used in this study

\begin{tabular}{|c|c|c|c|c|c|c|c|c|}
\hline \multirow[b]{2}{*}{ Code $^{a}$} & \multirow[b]{2}{*}{ Origin $^{\mathrm{b}}$} & \multirow[b]{2}{*}{ Color } & \multicolumn{5}{|c|}{ Biochemical $^{d}$} & \multirow[b]{2}{*}{ Taxonomic ${ }^{e}$} \\
\hline & & & AIA $^{f}$ & Celul. ${ }^{g}$ & Phos $^{h}$ & Sider. ${ }^{i}$ & Biofilm & \\
\hline BRM 32109 & GO/Brazil & White & - & + & + & + & + & Bacillus sp. \\
\hline BRM 32110 & PA/Brazil & White & - & + & + & - & + & Bacillus thunringiensis \\
\hline BRM 32111 & PA/Brazil & Yellow & - & + & + & + & + & Pseudomonas fluorescens \\
\hline BRM 32112 & GO/Brazil & Yellow & - & + & + & + & + & Pseudomonas sp. \\
\hline BRM 32113 & PA/Brazil & Pink & + & + & - & + & + & Burkholderia pyrroiynia \\
\hline BRM 32114 & PA/Brazil & Pink & + & + & + & + & + & Serratia sp. \\
\hline $\mathrm{Ab}-\mathrm{V} 5$ & PR/Brazil & Yellow & + & - & - & + & + & Azospirillum brasilense \\
\hline 1381 & & White & + & - & - & - & - & Azospirillum sp. \\
\hline 1301 & & White & & - & + & - & - & Bacillus sp. \\
\hline T- 26 & & Green & + & - & - & - & - & Trichoderma koningiopsis \\
\hline
\end{tabular}

a Numeric code of rhizobacteria and fungus isolates in the Embrapa Arroz e Feijão collection of Multifunctional Microorganisms;

${ }^{\mathrm{b}}$ Geographic source of each isolate;

$c, d, e$ Colony color, biochemical characterization and taxonomic classification of each isolate, described by Nascente et al. (2017a); Druzhinina et al. (2011);

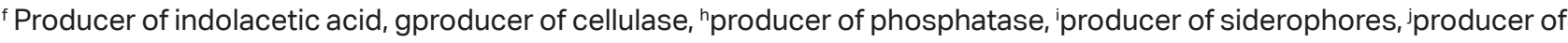
biofilm. The methodology is described in Nascente et al. (2017a); Druzhinina et al. (2011). 


\section{Microbiolization of seeds}

The bacterial suspensions for the microbiolization of the seeds and the preparation of the suspensions for irrigation and spraying were prepared with water from cultures that grew for a period of 24 hours in a solid medium 523 (Kado \& Heskett, 1970) at $28^{\circ} \mathrm{C}$, and the concentration was fixed in a spectrophotometer for $\mathrm{A} 540=0.5$ (108 CFU ml-1 for rhizobacteria and $1 \times 10^{8}$ conidia $\mathrm{ml}^{-1}$ for T. koningiopsis). The common bean seeds were immersed in each suspension of microorganisms, and the seeds of the controlled treatment were immersed in water for a period of 2 hours under a constant temperature at $25^{\circ} \mathrm{C}$, as described by Filippi et al. (2011) with adaptations for common bean.

Watering the soil: At 7 days after sowing (DAS), the soil was watered with $100 \mathrm{ml}$ of suspension in each treatment.

Leaf spraying: At 21 DAS, the plants were sprayed with $30 \mathrm{ml}$ of suspension for each treatment. The spraying was carried out using a manual sprayer with pressure supplied by a $\mathrm{CO}_{2}$ pressure source and a conical nozzle (TX-VS2).

\section{Management of common bean plants}

Ten common bean seeds, cultivar BRS UAl, were sown per pot. Ten days after germination, the plants were thinned, leaving three plants per pot. The cultural practices were carried out according to the recommendations and crop needs (Stone \& Sartorato, 1994).

\section{Assessments}

Gas exchange measurements: photosynthetic rate $\left(\mu \mathrm{mol} \quad \mathrm{CO}_{2} \quad \mathrm{~m}^{-2} \mathrm{~s}^{-1}\right)$,

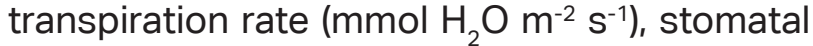

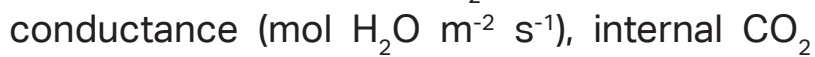
concentration (vpm) and leaf temperature $\left({ }^{\circ} \mathrm{C}\right)$ were determined in common bean plants using a portable gas meter in the IRGA infrared region (LCpro + ADC BioScientific) between 0800 and $1000 \mathrm{am}$. The measurements were obtained from the plants at 51 DAS, the full flowering stage (phenological stage R6). The readings were obtained in the central third of the first completely expanded trefoil (from top to bottom). The equipment was regulated to use concentrations of $370-400$ $\mathrm{mol}^{-1} \mathrm{CO}_{2}$ in the reference air used in the IRGA photosynthesis chamber. The flow density of photosynthetically active photons (DFFFA) used was 1,200 $\mu \mathrm{mol}$ [quanta] $\mathrm{m}^{-2} \mathrm{~s}^{-1}$. The minimum equilibrium time established for the readings was 2 minutes.

Biomass production: The shoot of one plant per pot was randomly cut and packed in a paper envelope at 51 DAS (full bloom). For the roots, immediately after the plants were harvested (77 DAS), the soil of each pot was washed and sieved to separate the roots. Then, the roots were packed in a paper envelope and identified. Both the shoots and roots were dried in a forced ventilation oven at $65^{\circ} \mathrm{C}$ until constant mass and weighed.

Concentration of nutrients: From the dry and weighed shoots and roots, as well as from the grains, representative aliquots were removed, which were ground to determine the 
levels of macronutrients ( $\mathrm{N}, \mathrm{P}$, and $\mathrm{K}$ ), following the recommendations of Malavolta, Vitti and Oliveira (1997).

Yield components and grain yield: The harvest was carried out when the common bean plants reached physiological maturity at 77 DAS. Thus, the number of pods per pot, number of grains per pod, mass of 100 grains and grain yield per pot were determined. The values obtained for the mass of the grains and grain yield were corrected for $13 \%$ humidity. These determinations were made in each pot.

\section{Statistical analysis}

The data were submitted to analysis of variance, and when significance was detected, the means were compared by the LSD test $(p \leq 0.05)$. The statistical package used was SISVAR. In addition, Pearson's correlation analysis was performed between all variables with biomass production, yield components and grain yield of common bean. For this, the SPSS package was used.

\section{Results and Discussion}

\section{Gas exchange evaluation}

The values of photosynthesis (A), transpiration (E), stomatal conductance (gs), leaf temperature $\left(\mathrm{T}^{\circ} \mathrm{C}\right)$ and internal $\mathrm{CO}_{2}$ concentration ( $\mathrm{Ci}$ ) were similar in the common beans treated with multifunctional microorganisms (Figure 1). As in this study, Nascente et al. (2017b), working with lowland rice, concluded that gas exchange was not affected by multifunctional microorganisms. Thus, we can conclude that MMs have minimal effects on these variables; however, they can have an effect on other variables related to grain yields. Observing the data corresponding to the gas exchange evaluations revealed that the variables were not affected by multifunctional microorganisms due to changes in the photosynthetic apparatus, with all other variables related to photosynthesis. Gas exchange is a complex event and can be influenced by several factors that control the success of plant-microorganism interactions (Ennahli \& Earl, 2005). In our research, multifunctional microorganisms did not express sufficient beneficial effects due to external (temperature, $\mathrm{pH}$, and humidity) and internal (nutrition and plant metabolism) factors influencing gas exchange in common bean plants. 

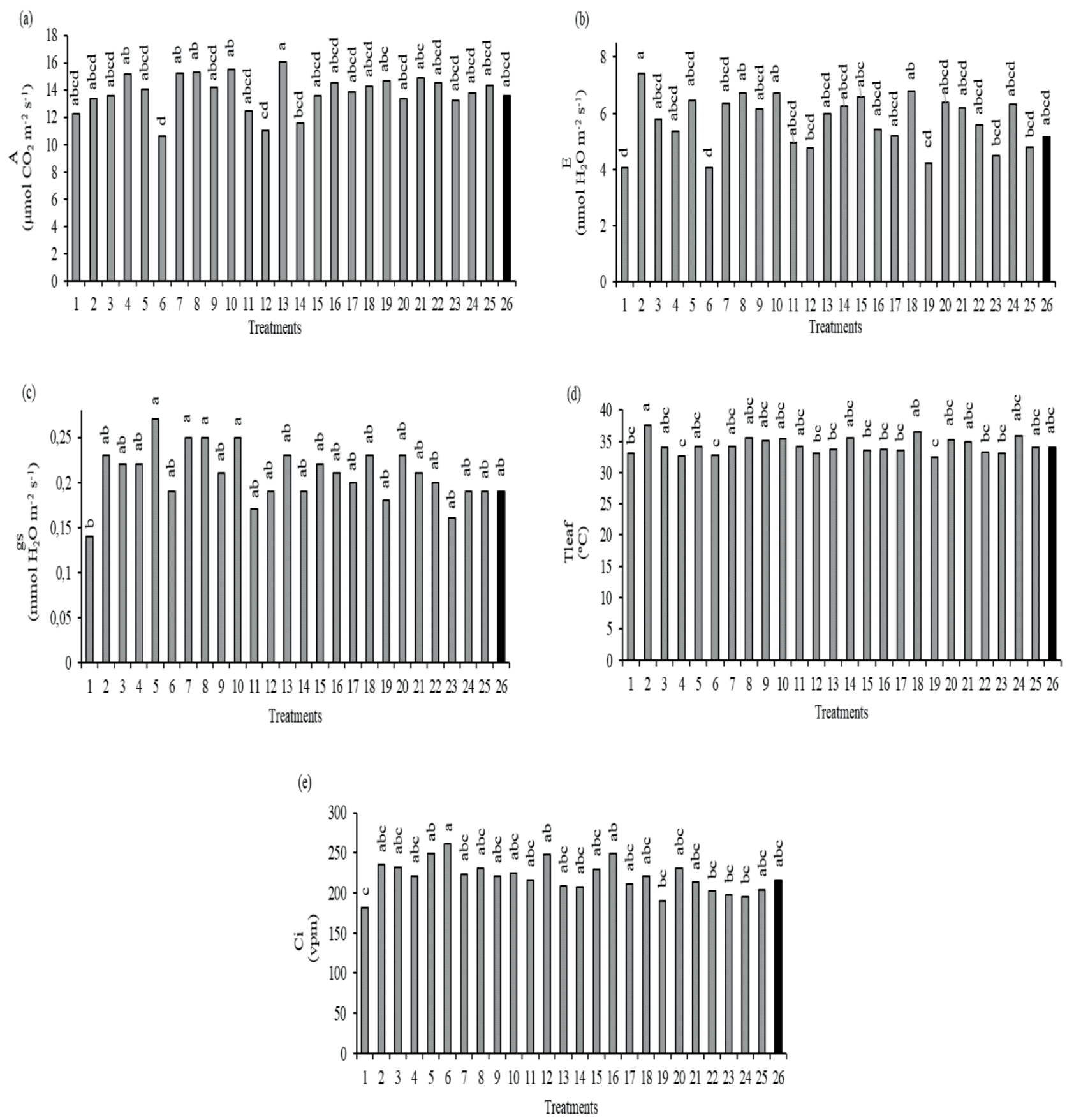

Figure 3. (a) Dry shoot biomass, (b) Dry root biomass and (c) Dry total biomass in common bean plants treated with multifunctional microorganisms, isolated or in combination. * Treatments followed by the same letter in columns do not differ from each other by the LSD test. ** Treatments: (1) BRM 32109; (2) BRM 32110; (3) BRM 32111; (4) BRM 32112; (5) BRM 32113; (6) BRM 32114; (7) T-26; (8) Ab-V5; (9) 1381; (10) 1301; (11) 32114 + 32110; (12) 32114 + Ab-V5; (13) 32114 + T-26; (14) $32110+$ Ab-V5; (15) $32110+$ T-26; (16) Ab-V5 + T-26; (17) $1381+1301 ;$ (18) $1381+$ Ab-V5; (19) $1301+$ Ab-V5; (20) $1381+32114 ;$ (21) $1301+32114 ;$ (22) $1381+32110 ;(23) 1301+32110 ;(24)$ $1381+$ T-26; (25) $1301+\mathrm{T}-26$; (26) control (without microorganism). 


\section{Biomass}

The accumulation of shoot biomass in common bean plants occurred when treated with microorganisms $1381+\mathrm{Ab}$ V5 (Figure 2). The increase in biomass was $23.5 \%$ compared to that in the control plants. Other treatments that stood out were T-26, $\mathrm{Ab}-\mathrm{V} 5+\mathrm{T}-26$ and $1301+\mathrm{Ab}-\mathrm{V} 5$, with an average increase equal to $18.0 \%$ in relation to that in the control plants. An increase of approximately $4.1 \mathrm{~g} \mathrm{~kg}^{-1}$ in root biomass was found in common bean plants treated with $1301+\mathrm{T}-26(4.3 \mathrm{~g})$ and Ab-V5 + T-26 (4.0 g) compared to that common bean plants in the control treatment. In relation to total biomass (root + shoots), values were significantly higher in common bean plants treated with $1381+$ $\mathrm{Ab}-\mathrm{V} 5, \mathrm{Ab}-\mathrm{V} 5+\mathrm{T}-26, \mathrm{~T}-26$, and $1301+\mathrm{Ab}-$ V5 than those in the other treatments. The average increment was $20 \%$ compared to that in the control plants. These results showed that together, Azospirillum brasilense (AbV5), Azopirillum sp. (1381), Bacillus sp. (1301) and Trichoderma koningiopsis (T-26) were the most efficient in promoting an increase in biomass in common bean plants. This increase in root and shoot biomass can be attributed to the direct mechanisms by which rhizobacteria act in the direct solubilization of insoluble $P$ sources, $\mathrm{N}$ fixation and/or the regulation of the concentration of plant growth regulators, such as indole acetic acid (AIA) produced by Azospirillum and Trichoderma. Benizri et al. (2001) and Hungria, Campo, Souza and Pedrosa (2010) reported that Azospirillum and Bacillus result in greater root development, which can result in several other beneficial effects on plants, such as greater absorption of water and nutrients, resulting in more vigorous and productive plants. 

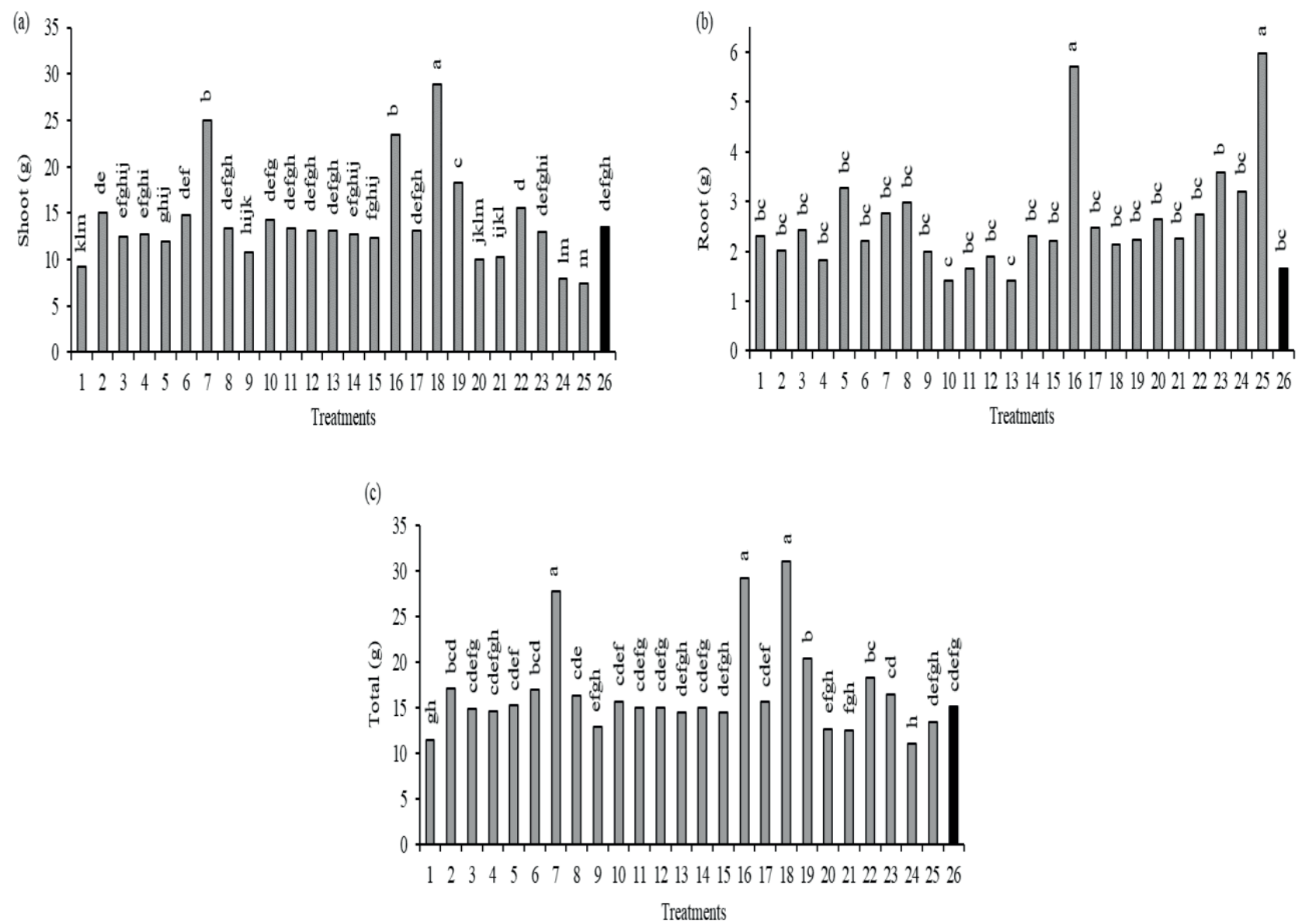

Figure 3. (a) Dry shoot biomass, (b) Dry root biomass and (c) Dry total biomass in common bean plants treated with multifunctional microorganisms, isolated or in combination. * Treatments followed by the same letter in columns do not differ from each other by the LSD test. ** Treatments: (1) BRM 32109; (2) BRM 32110; (3) BRM 32111; (4) BRM 32112; (5) BRM 32113; (6) BRM 32114; (7) T-26; (8) Ab-V5; (9) 1381; (10) 1301; (11) 32114 + 32110; (12) 32114 + Ab-V5; (13) 32114 + T-26; (14) $32110+\mathrm{Ab}-\mathrm{V} 5$; (15) $32110+\mathrm{T}-26$; (16) Ab-V5 + T-26; (17) $1381+1301 ;$ (18) $1381+\mathrm{Ab}-\mathrm{V} 5$; (19) $1301+$ Ab-V5; (20) $1381+32114$; (21) $1301+32114$; (22) $1381+32110 ;$ (23) $1301+32110 ;$ (24) $1381+$ T-26; (25) $1301+$ T-26; (26) control (without microorganism). 
The increase in root biomass was directly associated with the increase in biomass in the shoots of common bean plants (Figure 2), which can be attributed to increased water absorption and translocation of nutrients resulting from the increased area of contact between roots and soil and increased volume of root hair. The increase in shoot biomass can be attributed to the ability of rhizobacteria to induce the synthesis of gibberellins and cytokinins that regulate leaf expansion and chlorophyll synthesis (Rodriguez, Fragar, Gonzalez, \& Bashan, 2006).

Bacteria of the genera Azospirillum sp. and Bacillus sp. are diazotrophic and promote nitrogen fixation (Wang, Perez, Ye, \& Huang, 2012). As common bean plants demand substantial nutrients, mainly nitrogen, these isolates in combination may have directly contributed to the nitrogen nutrition of the common bean plants, favoring their growth (Spolaor et al., 2016). The promotion of plant growth by Trichoderma species occurs through the production of gibberellins and auxins such as AIA (Hermosa et al., 2013), which favor the development of lateral roots. Souza et al. (2012) observed that the most efficient isolates of Trichoderma spp. (T. harzianum, T. strigosum and T. theobromicola) increased the dry matter production of common bean shoots.

\section{Yield components and grain yield}

In comparison to the control plants, the common bean plants treated with the isolates BRM 32109, 1301, and BRM 32110 and with the combinations BRM $32114+$ BRM 32110, BRM $32110+$ T-26 and BRM 32114 $+\mathrm{Ab}-\mathrm{V} 5$ showed higher grain yield (Figure 3 ). The average increase was on the order of $6 \%$. In comparison to the control plants, the plants treated with BRM 32114 + BRM 32110 had a higher number of pods per pot (increase of $46.4 \%)$, and plants treated with T-26 had a greater mass of 100 grains (increase of $23.0 \%$ ). In addition, the number of grains per pod did not vary among treatments. 

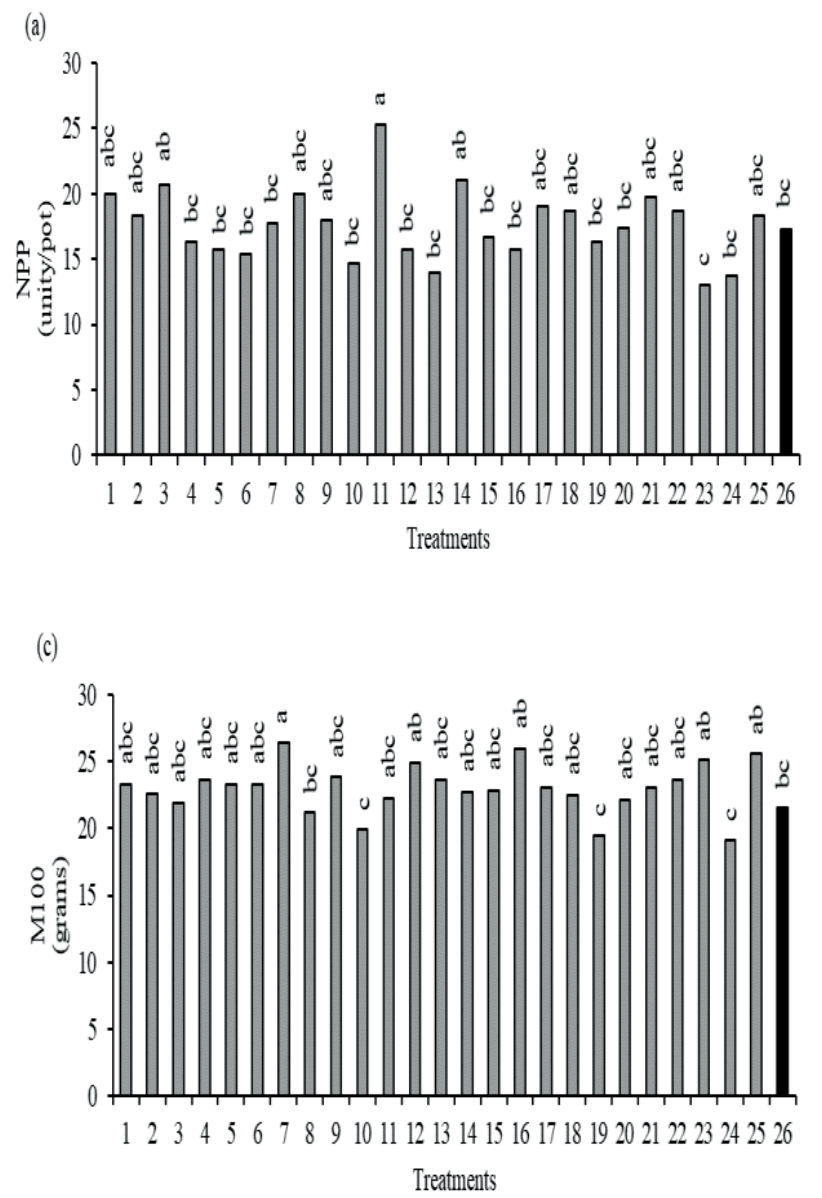

(b)
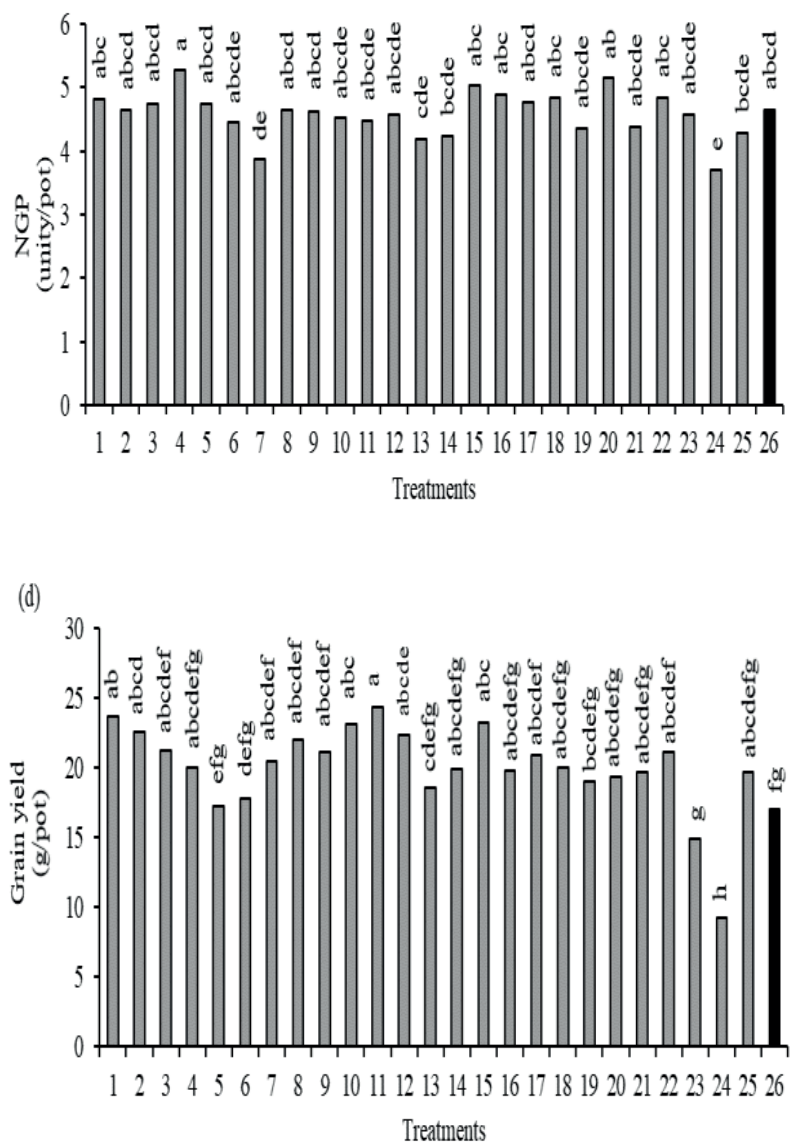

Figure 3. (a) Number of pods per pot, (b) Number of beans per pod, (c) Mass of 100 grains and (d) Grain yield common bean plants treated with multifunctional microorganisms, alone or in combination. * Treatments followed by the same letter in columns do not differ from each other by the LSD test. ** Treatments: (1) BRM 32109; (2) BRM 32110; (3) BRM 32111; (4) BRM 32112; (5) BRM 32113; (6) BRM 32114; (7) T-26; (8) Ab-V5; (9) 1381; (10) 1301; (11) 32114 + 32110; (12) 32114 + Ab-V5; (13) 32114 + T-26; (14) 32110 + Ab-V5; (15) 32110 + T-26; (16) Ab-V5 + T-26; (17) 1381 + 1301; (18) 1381 + Ab-V5; (19) 1301 + Ab-V5; (20) $1381+32114$; (21) 1301 + 32114; (22) 1381 + 32110; (23) 1301 + 32110; (24) 1381 + T-26; (25) 1301 + T-26; (26) control (without microorganism).

The increase in yield components and grain yields can be explained by the mechanisms of action of multifunctional microorganisms in common bean plants. The microorganisms that showed increased grain yields were the same microorganisms that showed increases in the macronutrient content of common bean plants. As already shown, the microorganisms influenced the biomass of the shoots and roots, nourishing the plants and making the plants better able to absorb water and nutrients, factors that directly influence the grain yield of a crop. In addition to improving soil structure, the development of the roots by microorganisms may also have increased the plants' ability 
to absorb water and nutrients, offering the plants the use of nutrients necessary for the development and filling of grains, as well as providing increased grain yield. For example, Lobo, Brandão and Geraldine (2009) also found increased productivity working with common bean and the application of $T$. asperellum and T. harzianum, and this increase was dependent on the dose of microorganisms applied. The application of T. asperellum (800 $\mathrm{mL} \mathrm{ha}^{-1}$ ) produced an increase of up to 807 $\mathrm{kg} \mathrm{ha}^{-1}$ in comparison to that of the control, and the application of T. harzianum $(1000 \mathrm{~mL}$ $\mathrm{ha}^{-1}$ ) generated an increase of $957 \mathrm{~kg} \mathrm{ha}^{-1}$ in comparison to that of to the control.

\section{Macronutrients in shoots, roots and grains}

Common bean plants treated with isolates 1381 and 1301, in addition to the combinations $1381+\mathrm{T}-26, \mathrm{Ab}-\mathrm{V} 5+\mathrm{T}-26$, BRM 32114 + BRM 32110, BRM $32110+$ Ab-V5, $1301+$ BRM 32110 and 1381 + BRM 32114, presented the highest levels of $\mathrm{N}$ in shoots (Figure 4). The average increase was on the order of $5.3 \%$. Regarding macronutrient $P$, common bean plants treated with isolate 1381 and with the combinations BRM $32114+$ BRM 32110, Ab-V5 + T-26 and $1381+\mathrm{T}-26$ showed significantly higher levels of $P$ than those of the control plants. The average increase was approximately $17.0 \%$. For macronutrient $\mathrm{K}$, common bean plants treated with the combination BRM 32114 + BRM 32110 showed significantly higher levels of $\mathrm{K}$ (and increase of $25.74 \%$ ) than those of the control plants.
Regarding the macronutrient content in the roots of common bean plants, the levels of $\mathrm{N}$ and $P$ were similar between treatments, while the $\mathrm{K}$ content was significantly higher in common bean plants treated with isolate 1301 and with the combination 1381 + BRM 32110 than in the control plants (Figure 4); the increments in the $\mathrm{K}$ content for these two treatments were on the order of $12.03 \mathrm{~g} \mathrm{~kg}^{-1}$ and $11.47 \mathrm{~g} \mathrm{~kg}^{-1}$, respectively. For grains, common bean plants treated with the combinations $1381+\mathrm{T}-26$ and $1301+$ BRM 32110 had a significantly higher $\mathrm{P}$ content (average increase of $10.3 \%$ ) than that of the plants in the other treatments, while plants treated with isolate 1301 had a significantly higher $\mathrm{K}$ content compared to that of the control plants (Figure 5). The increase was on the order of $3.82 \mathrm{~g} \mathrm{~kg}^{-1}$. For $\mathrm{N}$, there were no differences between the treatments.

Given the results obtained for root biomass and macronutrient content, microorganisms such as Ab-V5, 1301, and T-26, which stimulated the growth of roots, provided an increase in the contact area of the roots with consequently higher nutrient concentrations. Machado et al. (2012) also observed greater absorption of nutrients by plants treated with multifunctional microorganisms and suggested the most significant development of the roots and increased hairs on the roots as the main factors. Other microorganisms, such as BRM 32114, BRM 32110, and 1381, may have increased the efficiency of the biochemical mechanisms such as the absorption and assimilation of $\mathrm{N}$ and $\mathrm{P}$ to accumulate macronutrients in the shoot. 


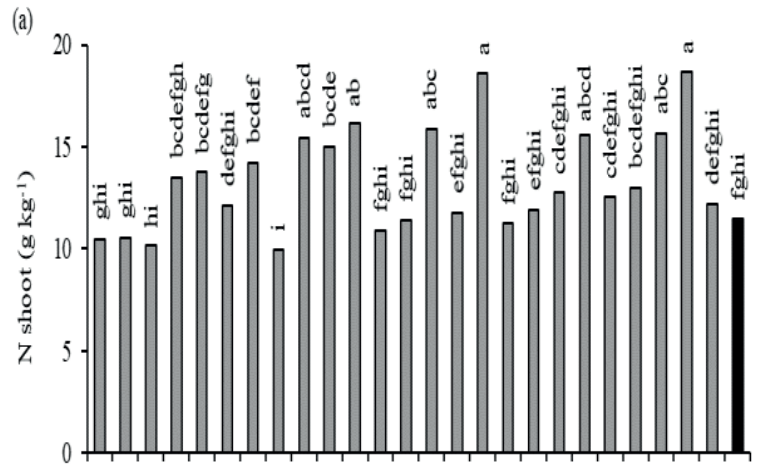

1234567891011121314151617181920212223242526 Treatments

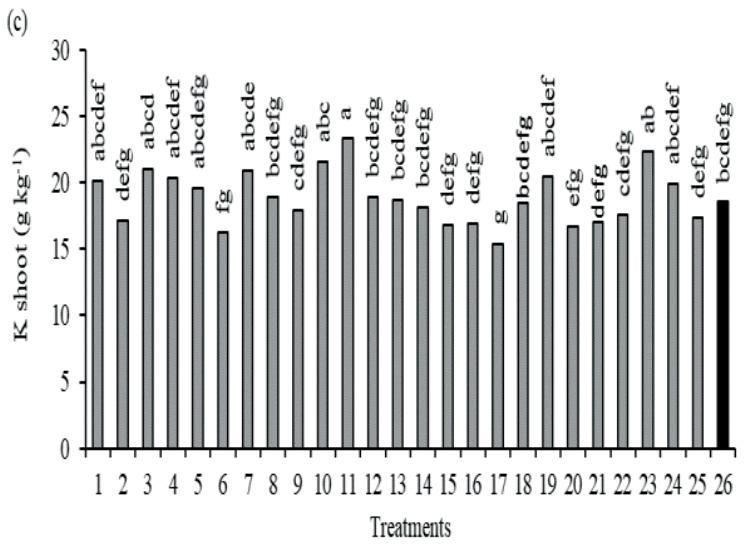

(e)

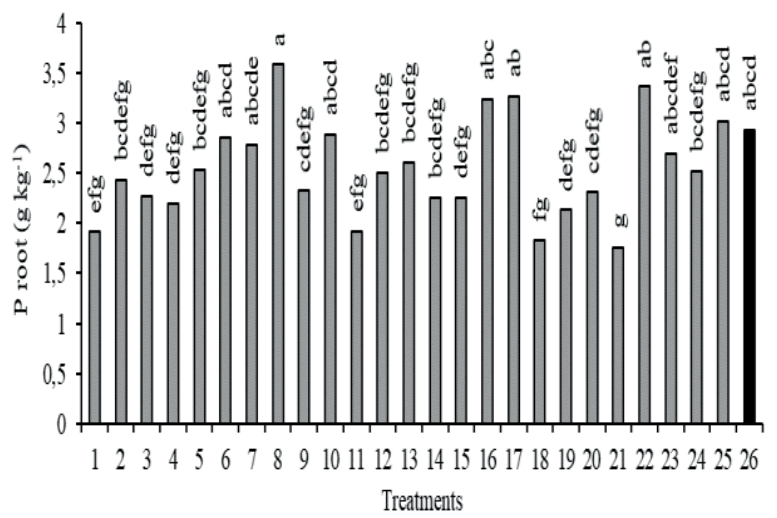

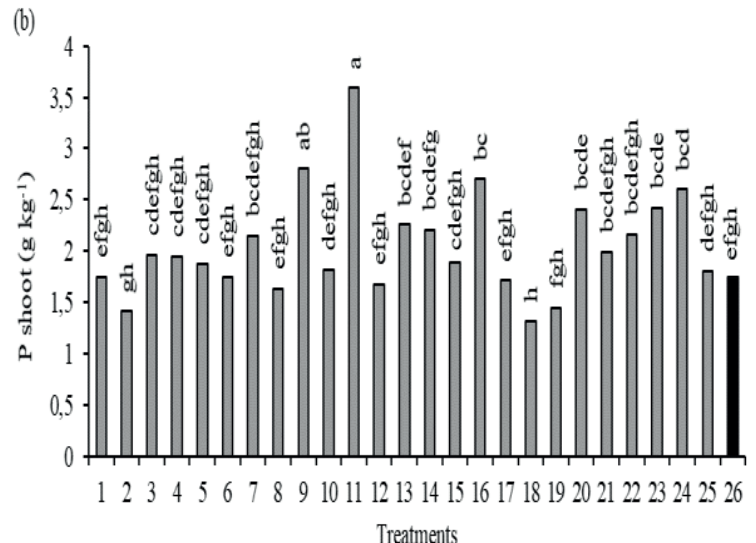

(d)

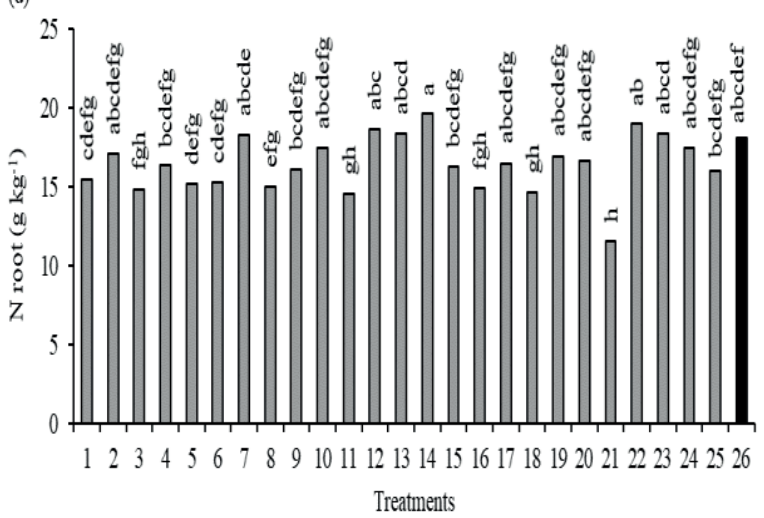

(f)

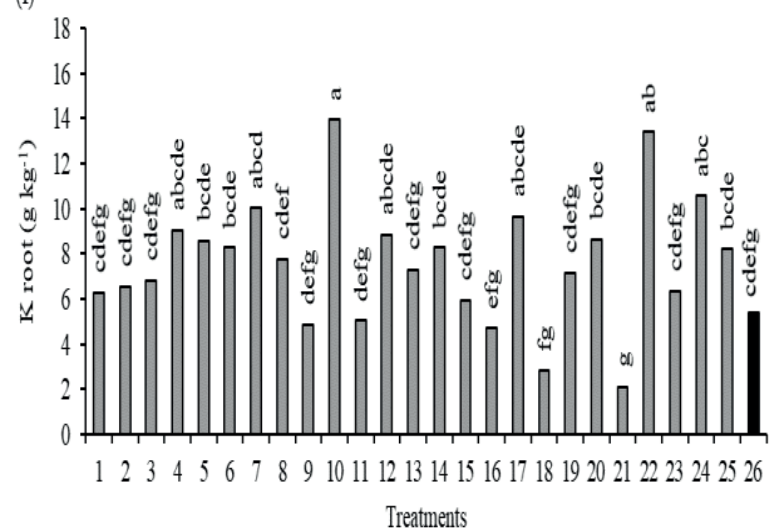

Figure 4. (a) Nitrogen, (b) Phosphorus and (c) Potassium in the shoot in common bean plants (d) Nitrogen, (e) Phosphorus and (f) Potassium in the root system in common bean plants treated with multifunctional microorganisms, isolated or in combination. * Treatments followed by the same letter in columns do not differ from each other by the LSD test. ** Treatments: (1) BRM 32109; (2) BRM 32110; (3) BRM 32111; (4) BRM 32112; (5) BRM 32113; (6) BRM 32114; (7) T-26; (8) Ab-V5; (9) 1381; (10) 1301; (11) $32114+32110 ;$ (12) $32114+$ Ab-V5; (13) $32114+\mathrm{T}-26$; (14) $32110+\mathrm{Ab}-\mathrm{V} 5$; (15) 32110 + T-26; (16) Ab-V5 + T-26; (17) $1381+1301 ;$; (18) $1381+$ Ab-V5; (19) $1301+$ Ab-V5; (20) $1381+32114 ;$; (21) $1301+32114 ;$ (22) $1381+32110 ;$ (23) $1301+32110 ;$ (24) 1381 + T-26; (25) $1301+$ T-26; (26) control (without microorganism). 

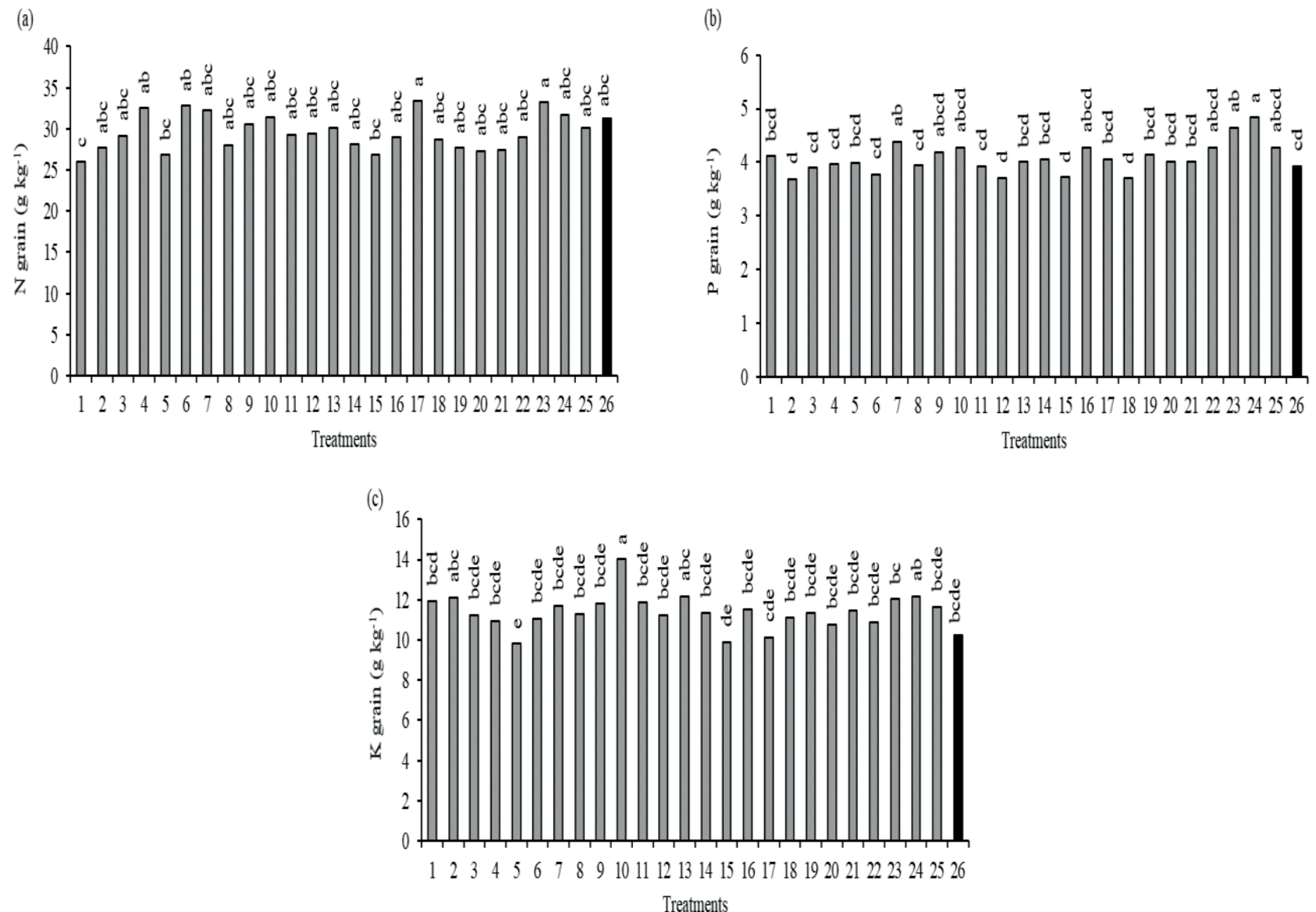

Figure 5. (a) Nitrogen, (b) Phosphorus and (c) Potassium in grains of common bean plants treated with multifunctional microorganisms, isolated or in combination. * Treatments followed by the same letter in columns do not differ from each other by the LSD test. ${ }^{* *}$ Treatments: (1) BRM 32109; (2) BRM 32110; (3) BRM 32111; (4) BRM 32112; (5) BRM 32113; (6) BRM 32114; (7) T-26; (8) Ab-V5; (9) 1381; (10) 1301; (11) $32114+32110$; (12) $32114+$ Ab-V5; (13) $32114+$ T-26; (14) $32110+$ AbV5; (15) $32110+$ T-26; (16) Ab-V5 + T-26; (17) $1381+1301$; (18) $1381+$ Ab-V5; (19) $1301+$ Ab-V5; (20) $1381+32114 ;$ (21) $1301+32114$; (22) $1381+32110 ;$; (23) $1301+32110 ;$ (24) $1381+$ T-26; (25) $1301+$ T-26; (26) control (without microorganism).

In addition, multifunctional microorganisms can benefit plants through their ability to solubilize some nutrients and make them available to the plant, contributing to greater growth (Chaudhary \& Sindhu, 2016); this result was observed in the present study, where multifunctional microorganisms induced the accumulation of $\mathrm{K}$ in roots and grains and positively influenced the growth of common bean plants.
Grainyield showedapositive correlation with the number of pods $\left(0.541^{* *}\right)$, while shoot biomass correlated positively with the variables total biomass $\left(0.330^{* *}\right)$ and mass of 100 grains $\left(0.298^{* *}\right)$ (Table 3). The root biomass was highly correlated with the total biomass $\left(0.962^{* *}\right)$. The results showed that grain yield was related to variables such as production and biomass components, showing a dependence between grain yield and the variation of these variables. 
These variables directly influenced the grain yield of common bean plants. Confirming this explanation, this result is in line with that described by Balbinot, Ferreira, Werner, Aguiar e Silva and Zucareli (2018), who showed a positive correlation between the growth of soybean plants and grain yield.

\section{Table 3}

Pearson's correlation coefficient values between gas exchange variables, biomass, grain production and productivity and nutrient content

\begin{tabular}{|c|c|c|c|c|c|c|c|}
\hline & Bshoot $^{a}$ & Broot $^{b}$ & Btotal $^{c}$ & N. pods ${ }^{d}$ & N. grains ${ }^{e}$ & $M 100^{f}$ & Grain yields \\
\hline Bshoot $^{a}$ & - & 0.061 & $0.330 * *$ & -0.071 & 0.01 & $0.298^{* *}$ & -0.178 \\
\hline Broot $^{b}$ & - & - & $0.962^{* *}$ & -0.03 & 0.029 & 0.143 & 0.073 \\
\hline Btotal $^{\mathrm{c}}$ & - & - & - & -0.048 & 0.03 & 0.215 & 0.021 \\
\hline N. pods ${ }^{d}$ & - & - & - & - & 0.011 & 0.077 & $0.541^{* *}$ \\
\hline N.grains ${ }^{e}$ & - & - & - & - & - & 0.009 & 0.2 \\
\hline $\mathrm{M} 100^{f}$ & - & - & - & - & - & - & 0.18 \\
\hline Grain yield ${ }^{g}$ & - & - & - & - & - & - & - \\
\hline$A^{h}$ & 0.061 & 0.101 & 0.112 & 0.054 & -0.127 & -0.057 & 0.027 \\
\hline $\mathrm{E}^{\mathrm{i}}$ & -0.085 & 0.101 & 0.072 & 0.118 & 0.143 & -0.205 & 0.096 \\
\hline$g^{j}$ & -0.044 & 0.179 & 0.157 & 0.109 & 0.03 & -0.114 & 0.148 \\
\hline $\mathrm{ci}^{\mathrm{k}}$ & -0.04 & 0.148 & 0.129 & -0.023 & 0.227 & -0.013 & 0.131 \\
\hline Tleaf $^{\prime}$ & -0.006 & 0.042 & 0.038 & 0.093 & 0.046 & -0.195 & 0.019 \\
\hline Nshoot $^{m}$ & $0.261^{*}$ & 0.069 & 0.137 & $0.337^{* *}$ & -0.179 & -0.135 & $0.389^{* *}$ \\
\hline Pshoot $^{n}$ & 0.122 & -0.129 & -0.088 & 0.059 & -0.034 & -0.03 & -0.117 \\
\hline Kshoot $^{\circ}$ & -0.062 & 0.101 & 0.078 & 0.049 & -0.092 & -0.142 & 0.048 \\
\hline Nroot $^{p}$ & -0.075 & 0.045 & 0.022 & -0.219 & -0.172 & 0.159 & -0.189 \\
\hline Proot $^{q}$ & $0.326^{* *}$ & 0.041 & 0.127 & -0.134 & -0.082 & 0.168 & -0.142 \\
\hline Kroot $^{r}$ & 0.083 & -0.104 & -0.076 & $0.234^{*}$ & -0.044 & -0.035 & -0.163 \\
\hline Ngrain $^{s}$ & -0.125 & 0.046 & 0.009 & -0.088 & $0.364^{* *}$ & $0.310^{* *}$ & -0.049 \\
\hline Pgrain $^{t}$ & 0.119 & -0.076 & -0.039 & 0.074 & -0.09 & 0.096 & -0.18 \\
\hline Kgrain ${ }^{u}$ & -0.046 & -0.051 & -0.061 & $-0.238^{*}$ & $-0.270^{*}$ & -0.175 & 0.004 \\
\hline
\end{tabular}

** The correlation is significant at the 0.01 level ( 2 extremities)

*The correlation is significant at the 0.05 level ( 2 extremities)

aDry shoot biomass, bry root biomass, 'Dry total biomass, dNumber of pods per pot, eNumber of beans per pot,

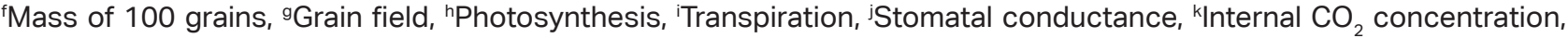
'Leaf temperature, mNitrogen, nPhosphorus, ${ }^{\circ}$ Potassium shoot, ${ }^{\mathrm{P} N i t r o g e n, ~}{ }^{\mathrm{P} P h o s p h o r u s, ~ ' P o t a s s i u m ~ r o o t, ~}{ }^{\mathrm{s} N i t r o g e n,}$ tPhosphorus, uPotassium grains. 
For macronutrients, a positive correlation was observed between the $\mathrm{N}$ content in the shoots and shoot biomass, number of pods and grain yield $(0.261 * ; 0.337 *$; and $0.389^{* *}$, respectively) (Table 3 ). A positive correlation was also observed between $\mathrm{N}$ in the grain and the number of grains per pod $\left(0.364^{* *}\right)$ and mass of 100 grains $\left(0.310^{* *}\right)$. With these results, the relationship between the $\mathrm{N}$ content and yield components was evident since $\mathrm{N}$ is an essential nutrient for the growth and development of plants, particularly common bean. There was also a positive correlation between the $\mathrm{P}$ content in the root and shoot dry biomass shoot $\left(0.326^{* *}\right)$ and a negative correlation between the $\mathrm{K}$ content in the grain and the number of pods per plant $\left(-0.238^{*}\right)$ and the number of grains per plant $\left(-0.270^{*}\right)$ (Table 3). For the relationship between these variables, it can be inferred that several characteristics of the plants were influenced by the level of $P$ available to the common bean plant, some of which were positive and others were negative. Furlani, Bataglia, Furlani, Azzini and Camargo (1983) verified, through correlation coefficients, that the tolerance to $\mathrm{Al}$ is related to the efficiency of $\mathrm{P}$ for one hundred lines of irrigated upland rice and forty maize and found that in conditions of low availability of $P$, the shoot biomass and roots were the characteristic that was most related to the efficiency of use of $P$ and allowed the differentiation of rice genotypes.

This study showed that multifunctional microorganisms other than Rhizobium produce beneficial effects on the growth and development of common bean plants. Therefore, it is imperative to advance knowledge through scientific research to establish economically viable types and quantities of application for these bioinputs, as well as to validate these results in experiments under field conditions.

\section{Conclusions}

The microorganisms used in this study resulted in significant increases in shoot and root biomass and levels of $\mathrm{N}, \mathrm{P}$, and $\mathrm{K}$ with direct effects on yield components and grain yield of common bean plants.

The multifunctional microorganisms Azospirillum brasilense (Ab-V5), Azospirillum sp. (1381), Bacillus thuringiensis (BRM 32110), Bacillus sp. (1301), Trichoderma koningiopsis. (T-26) and Serratia sp. (BRM 32114) were the microorganisms that stood out as having beneficial effects on common bean plants.

\section{Acknowledgments}

The authors would like to thank Brazilian Agricultural Research Corporation (EMBRAPA) for the infrastructure for performing this research, Brazilian Council for Scientific and Technological Development (CNPq) for support this research (process n. 406507/2018-0) and for the research productivity scholarship for the sixth and seventh authors, and to the Coordination for the Improvement of Higher Education Personnel (CAPES) for providing the master's scholarship to the first author.

\section{References}

Balbinot, A. A., Jr., Ferreira, A. S., Werner, F., Aguiar e Silva, M. A. de, \& Zucareli, C. (2018). Crescimento de plantas de soja em função da redução da densidade de semeadura e sua relação com a produtividade. Embrapa Soja. Boletim 
de Pesquisa e Desenvolvimento, 18). Londrina: EMBRAPA Soja. Recuperado de https://www.infoteca.cnptia.embrapa. br/infoteca/bitstream/ doc/1099933/1/ BOLETIMPB18Alvadi.pdf

Benizri, E., Baudoin, E., \& Guckert, A. (2001). Root colonization by inoculated plant growthpromoting rhizobacteria. Biocontrol Science and Technology, 11(5), 557-574. doi: 10.1080/09583150120076120

Chagas, L. F. B., Chagas, A. F., Jr., Soares, L. P., \& Fidelis, R. R. (2017). Trichoderma in promoters of plant growth. Revista de Agricultura Neotropical, 4(3), 97-102. doi: 10.32404/rean.v4i3.1529

Chaudhary, S. R., \& Sindhu, S. S. (2016). Growth stimulation of clusterbean (Cyamopsis tetragonoloba) by coinoculation with rhizosphere bacteria and Rhizobium. Legume Research, 39(6), 1003-1012. doi: 10. $18805 /$ Ir.vOiOF.8605

Chibeba, A. M., Guimarães, M. F., Brito, O. R., Nogueira, M. A., Araújo, R. S., \& Hungria, M. (2015). Co-inoculation of soybean with Bradyrhizobium and Azospirillum promotes early nodulation. American Journal of Plant Sciences, 6(10), 16411649. doi: 10.4236/ajps.2015.610164

Dey, R., Pal, K. K., Bhatt, D. M., \& Chauhan, S. M. (2004) Growth promotion and yield enhancement of peanut (Arachis hypogaea L.) by application of plant growth promoting rhizobacteria. Microbiological Research, 159(4), 371-394. doi: 10.1016/j. micres.2004.08.004

Donagema, G. K., Campos, D. V. B., Calderano, S. B., Teixeira, W. G., \& Viana, J. H. M. (2011). Manual de métodos de análise do solo. Rio de Janeiro, RJ: EMBRAPA Solos.
Druzhinina, I. S., Seidl-Seiboth, V., HerreraEstrella, A., Horwitz, B. A., Kenerley, C. M., Monte, E.,... Kubicek, C. P. (2011). Trichoderma: the genomics of opportunistic success. Nature Reviews Microbiology, 16(9), 749-759. doi: 10.10 38/nrmicro2637

Ennahli, S., \& Earl, H. J. (2005). Physiological limitations to photosynthetic carbon assimilation in cotton under water stress. Crop Science, 45(6), 2374-2382. doi: 10.2135/cropsci2005.0147

Faria, J., Aragão, F., Souza, T., Quintela, E., Kitajima, E., \& Ribeiro, S. (2016). Golden mosaic of common beans in Brazil: management with a transgenic approach. Archives of Microbiology, 159(10), 727737. doi: 10.1094/APSFeature-2016-10

Filippi, M. C. C., Silva, G. B., Lobo, V. L. S., Cortes, M. V. C. B., Moraes, A. J. G., \& Prabhu, A. S. (2011). Leaf blast (Magnaporthe oryzae) suppression and growth promotion by rhizobacteria on aerobic rice in Brazil. Biological Control, 58(2), 160-166. doi: 10.1016/j.biocontrol.2011.04.016

França, S. K. S., Cardoso, A. F., Lustosa, D. C., Ramos, E. M. L. S., Filippi, M. C. C., \& Silva, G. B. da. (2015). Biocontrol of sheath blight by Trichoderma asperellum in tropical lowland rice. Agronomy for Sustainable Development, 35(1), 317-324. doi: 10.10 07/s13593-014-0244-3

Furlani, A. M. C., Bataglia, O. C., Furlani, P. R., Azzini, L. E., \& Camargo, O. B. (1983). Avaliação de genótipos de arroz quanto a eficiência no uso de fósforo em solução nutritiva e no solo. Revista Brasileira de Ciência do Solo, 7(3), 291-303. doi: 10.1590/S0006-87051991000200012 
Ganascini, D., Laureth, J. C. U., Mendes, I. S., Tokura, L. K., Sutil, E. L. V., Villa, B. de,... Coelho, S. R. M. (2019). Analysis of the production chain of bean culture in Brazil. Journal of Agricultural Science, 11(7), 256-267. doi: 10.5539/jas.v11n7p256

Glick, B. R. (2012). Plant growth-promoting bacteria: mechanisms and applications. Scientifica, 2012(5), 1-15. doi: 10.6064/ 2012/963401

Hermosa, R., Rubio, M. B., Cardoza, R. E., Nicolas, C., Monte, E., \& Gutiérrez, S. (2013). The contribution of Trichoderma to balancing the costs of plant growth and defense. International Microbiology, 16(2), 69-80. doi: 10.2436/20.1501.01.181

Hungria, M., Campo, R. J., Souza, E. M., \& Pedrosa, F. O. (2010). Inoculation with selected strains of Azospirillum brasilense and Azospirillum lipoferum improves yields of maize and wheat in Brazil. Plant and Soil, 331(13), 413-425. doi: 10.1007/ s11104-009-0262-0

Kado, C. J., \& Heskett, M. G. (1970). Selective media for isolation of Agrobacterium, Corynebacterium, Erwinia, Pseudomonas and Xanthomonas. Phytopathology, 60(6), 969-976. doi: 10.1094/Phyto-60-969

Lobo, M., Jr., Brandão, R. S., \& Geraldine, A. M. (2009). Produtividade do feijoeiro comum em campo em tratamentos com Trichoderma harzianum e Trichoderma asperellum. (Comunicado Técnico). Santo Antônio de Goiás: EMBRAPA Arroz e Feijão. Recuperado de https://www. embrapa.br/busca-de-publicacoes/-/ publicacao/663620/produtividadedo-feijoeiro-comum-em-campoem-tratamentos-com-trichodermaharzianum-e-trichoderma-asperellum
Machado, D. F. M., Parzianello, F. R., Silva, A. C. F. da, \& Antoniolli, Z. I. (2012). Trichoderma in Brazil: The fungus and the bioagent. Revista de Ciências Agrárias, 35(1), 274288. doi: 10.19084/rca.16182

Malavolta, E., Vitti, G. C., \& Oliveira, S. A. (1997). Avaliação do estado nutricional de plantas: princípios e aplicações. Piracicaba: Potafos.

Nascente, A. S., Filippi, M. C. C. de, Lanna, A. C., Souza, A. C. A., Lobo, V. L. S., \& Silva, G. B. da. (2017a). Biomass, gas exchange, and nutrient contents in upland rice plants affected by application forms of microorganism growth promoters. Environmental Science and Pollution Research, 24(3), 2956-2965. doi: 10.1007/ s11356-016-8013-2

Nascente, A. S., Filippi, M. C. C. de, Lanna, A. C., Sousa, T. P., Souza, A. C. A., Silva Lobo, V. L. da, \& Silva, G. B. da. (2017b). Effects of beneficial microorganisms on lowland rice development. Environmental Science and Pollution Research, 24(32), 25233-25242. doi: 10.1007/s11356-017-0212-y

Nascente, A. S., Filippi, M. C. C. de, Sousa, T. P. de, Chaibub, A. A., Souza, A. C. de, \& Lanna, A. C. (2019b). Upland rice gas exchange, nutrient uptake and grain yield as affected by potassium fertilization and inoculation of the diazotrophic bacteria Serratia spp. Australian Journal of Crop Science, 13(6), 944-953. doi: 10.21475/ajcs.19.13.06. p1689

Nascente, A. S., Lanna, A. C., Sousa, T. P. de, Chaibub, A. A., Souza, A. C. A. de, \& Filippi, M. C. C. de. (2019a). N fertilizer dosedependent efficiency of Serratia spp. for improving growth and yield of upland rice (Oryza sativa L.). International Journal 
of Plant Production, 13(3), 217-226. doi: 10.1007/ s42106-019-00049-5

Oliveira, F. C., Benett, C. G. S., Benett, K. S. S., Silva, L. M., \& Vieira, B. C. (2017). Different doses and times of application of zinc in soybean culture. Revista de Agricultura Neotropical, 4(5), 28-35. doi: 10. 32404/ rean.v4i5.2188

Oliveira, G. R. F., Silva, M. S., Marciano, T. V. F., Proença,S.L.,\&Sá,M.E. (2016). Earlygrowth of common bean plants in response to vigour seeds and inoculation with Bacillus subtilis. Brazilian Journal of Biosystems Engineering, 10(4), 439-448. doi: 10.180 11/bioeng2016v10n4p439-448

Podile, A. R., \& Kishore, G. K. (2006). Plant growth-promoting rhizobacteria. In S. S. Gnanamanickam (Ed.), Plant associated bacteria (pp. 195-230). Netherlands: Springer.

Rodriguez, H., Fragar, R., Gonzalez, T., \& Bashan, Y. (2006). Genetics of phosphate solubilization and its potential applications for improving plant groth-promoting bactéria. Plant and Soil, 287(1), 15-21. doi: 10.1007/s11104-006-9056-9

Souza, E. A. S. P., Harakava, R., Lucon, C. M. M., \& Guzzo, S. D. (2012). Plant growth promotion of common bean and anthracnose control by Trichoderma spp. Pesquisa Agropecuária Brasileira, 47(11), 1589-1595. doi: 10.1590/S0100204X2012001100005
Spolaor, L. T., Gonçalves, L. S. A., Santos, O. J. A. P. dos, Oliveira, A. L. M. de, Scapim, C. A., Bertagna, F. A. B., \& Kuki, M. C. (2016). Plant growth-promoting bacteria associated with nitrogen fertilization at topdressing in popcorn agronomic performance. Bragantia, 75(1), 33-40. doi: 10.1590/1678-4499.330

Stone, L. F., \& Sartorato, A. (1994). O cultivo do feijão: recomendações técnicas. (EMBRAPA-CNPAF. Documentos, 48). Brasília: EMBRAPA-SPI. Recuperado de http://ainfo.cnptia.embrapa.br/digital/ bitstream/CNPAF/11844/1/doc_48.pdf

United States Department of Agriculture (1996). Keys to soil taxonomy. Washington, USDA: Department of Agriculture.

Wang, S., Perez, P. G., Ye, J., \& Huang, D. F. (2012). Abundance and diversity of nitrogen-fixing bacteria in rhizosphere and bulk paddy soil under different duration of organic management. World Journal Microbiology Biotechnology, 28(5), 55605568. doi: 10.1007/s11274-011-0840-1 